\title{
KEMÉNY FERENC ÉS A NEMI NEVELÉS PEDAGÓGIAI KONCEPCIÓJA
}

\section{THE PEDAGOGICAL CONCEPT OF SEX EDUCATION BY FERENC KEMÉNY}

\author{
Forrai Judit \\ DSc, egyetemi tanár \\ Semmelweis Egyetem Népegészségtani Intézet, Wesley János Lelkészképző Főiskola \\ forraijud@gmail.com
}

\begin{abstract}
ÖSSZEFOGLALÁS
A szexualitás nagyon érzékeny kérdés a történelemben - még ma is -, a róla és ellene hozott intézkedések nemcsak az egyének magánéleti cselekvéseit érintik, hanem ezen cselekmények társadalomra gyakorolt "káros" következményeit is. Történelmileg a szexuális politika kiemelkedő szerepet játszott. A szexualitás az emberiség történelmén keresztül gyakran pánikhatásokat okozott, s e viselkedések különböző formáit megrögzött sztereotípiákká, erkölcsi normákká és szerepmodellekké formálták, amelyek közül a legfontosabbakat a közösség (népi hiedelmek, szokások, mítoszok formájában), de különösen a 19. század fordulóján a papok, az orvosok, a tanárok, a gondozók és a családok alakították ki. A 18. században a szexuális nevelés első lépése, célpontja a maszturbáció megakadályozása volt. A tizenkilencedik század végén a szifilisz nemzetközi járványának megfékezése lett a cél. Az egyik fontos lehetőséget az iskolai oktatás nyújtotta, amely a szexuális neveléssel, a tantervfejlesztés és az oktatásmódszertani lehetőségek előkészítése révén elősegítette a fertőzések megelőzését. Különös figyelmet fordítottak a fiúk nemi nevelésére, a sport hatékony szerepére. Magyarországon Kemény Ferenc fontos szerepet játszott abban, hogy elindítsa a középiskolai oktatást. Kemény tanár és humanista volt, nemzetközileg elismert szakember, a Nemzetközi Olimpiai Bizottság alapító tagja és a kortárs békemozgalmak szereplője. Kemény hangsúlyt fektetett a testnevelésre, az egészséges mentális és érzelmi oktatásra, melyben nagy szerepet kaptak a megfelelő versek és könyvek.
\end{abstract}

\section{ABSTRACT}

Sexuality is a very sensitive issue in history - even today - the measures taken with and against it affect not only the actions and private lives of individual people but also the 'damaging' consequences of these acts on society. Sexual politics played a prominent role in history. Sexuality, through the history of mankind, often caused panic effects. Different forms of behaviour are forced into confirmed stereotypes, moral norms, role models, the most important of which would be formed by the community (popular beliefs, customs, myths), especially through teaching by priests, doctors, teachers, carers, family at the turn of the $19^{\text {th }}$ century. In the $18^{\text {th }}$ century the first step in the sexual education was to prevent masturbation. At the end of the $19^{\text {th }}$ century curbing the international epidemic of syphilis became the target. Syphilis-avoidance and prevention 
became very important social issues, so school education was one obvious field to promote it by curriculum development and the preparation of teaching and methodological possibilities. Particular attention was paid to sex education and the effective role of sport for boys. Ferenc Kemény, who was a Hungarian educator and humanist, internationally recognised for being a founding member of the International Olympic Committee and his role in the contemporary peace movement, played a major role in starting secondary school education. Kemény put a strong emphasis on physical education, healthy mental and emotional education, where also poems and books were given important roles.

Kulcsszavak: történelem, szex edukáció, Kemény Ferenc, sport, századforduló

Keywords: history, sex education, Ferenc Kemény, sports, turn of $19^{\text {th }}$ century

A szexualitás nagyon érzékeny témákat érintett a történelem folyamán - még napjainkban is -, a velük, róluk, értük és ellenük hozott intézkedések nem csupán az emberek magánéletükben elkövetett tetteiről, hanem e cselekedetek társadalomra nézve ,káros” következményeiről is szóltak. A szexualitás az emberiség történetén végighaladva többnyire pánikjelenségeket váltott ki. A különböző viselkedési formákat sztereotípiákba, erkölcsi normákba, szerepmodellekbe kényszerítették, aminek legfontosabb eszköze a nevelés, amely a család és a közösség (néphit, szokások, hiedelmek, mítoszok) és/vagy szakavatott - vagy annak vélt - nevelök (papok, orvosok, tanítók, gondozók stb.) által valósult meg. A szexuális identitásról alkotott elképzelések a társadalmakban olyan közösségi érzéseket indukáltak, amelyek hatására bizonyos vágyakat, cselekedeteket tabunak tekintettek. A nemkívánatos jelenségeket deviánsnak tartották, marginalizálták és kizárták. A nevelés legfontosabb kérdései: mikor, ki, hogyan, hol és mit mondjon a szexualitásról.

A magánéleti kultúra, ezen belül a szexuális élet szokásainak intézményesített és családi nevelését vizsgálva a 18. századtól társadalmi diskurzus indul el az intézményesített formában történő nevelés tematikájáról és módszeréről. Míg a 18. században kezdődő restriktív szexuális szabályozás (Buda, 1994) első lépése a maszturbáció vagy, ahogy akkor nevezték, az onánia tilalma, a 19. századra a hangsúly a gyerekszületés körülményeire, a század végén pedig már a népbetegséggé vált nemi betegség, a szifilisz elkerülésének tantervi kidolgozása és tanítási módszertani lehetőségei felé tolódott el. Külön foglalkoztak a fiúk szexuális nevelésével, a sport hatékony szerepével.

Gazdasági-politikai érdekek miatt demográfiai tényezővé vált a házasság, a termékenység, a szaporodás, a halálozás és a különböző szexuális úton terjedő betegségek megakadályozása, ezek intézményes hátterének kialakítása (orvosképzés, egyetem, kórház, szakellátás, gyógyszerkutatás, biztosítás, megelőzés stb.). Mindezeket törvényi és morális előírások szabályozták. 
„A nemiség immár nemcsak a morális ítéleteknek tárgya, hanem az ügyintézésé is. A szexualitást, amely a közhatalomnak van alárendelve és a gazdaságirányítási eljárások alkalmazási területe, az elemző diskurzusok veszik birtokukba. A nemiség a 18. században »igazgatási« üggyé válik. A 18. században »igazgatáson « nem is annyira a rendbontás elfojtását értették, mint inkább a kollektív és egyéni erők sajátos rend szerinti megszervezését." (Foucault, 1996)

\section{A SZEXUÁLIS NEVELÉS INTÉZMÉNYESEDÉSE}

A magánéleti ismeretek szabályozása hagyományosan nem az iskola, hanem a család, illetve a templom kompetenciájába tartozott. Mindez különösen igaz volt a szexuálpedagógiával kapcsolatban.

A 19. század végén a szekularizáció nagyarányú elöretörése a német és magyar kultúrharc, az angol liberálisok és az anglikán egyház konfliktusai, a francia radikálisok szeparációs lépései az egész kontinensen új korszakot nyitottak az államilag kívánatosnak tartott erkölcsi viselkedés iskolai közvetítésében. Az iskola, illetve a társadalmi közbeszéd fokozatosan megkezdte a szekuláris morál integrálását, a keresztény erkölcstan kiegészítését, illetve relativizálását. Mindez természetessé tette, hogy a szexualitásra és a házasságra vonatkozó katolikus és protestáns tanítások mellett világi - konzervatív, liberális, radikális, feminista, szocialista - tanítások is felléptek, s fokozatosan teret nyertek az iskolában, az iskolán kívüli nemi nevelés intézményes, civil (például egyesületi formáiban), illetve a családi nevelésre ható irodalomban.

Így a szexuális nevelés, ha egyáltalán volt, a családon belüli határait szétszakítva elvesztette az „intimitását”, és különböző szinteken különböző célcsoportok számára közfeladattá vált: a fiataloknak a nemi betegségek megelőzése iskolai közoktatási feladat lett, a felnőttek számára civil szervezetek segítségével (oktatás, szórólapok, könyvek) országos közegészségügyi feladatként jelent meg.

Mindegyik területen jelentős szerepet játszottak a történelmi egyházak, a világi értelmiség (írók, orvosok, újságírók, tanárok) és az államgépezet.

Az egyetemi oktatásban 1901-ben vezettek be új tantervet Magyarországon. Az új szigorlati rend értelmében azonban még csupán szabadon választható tárgy lett a bujakór (ma venerológia, illetve bör- és nemi betegségek tantárgy). A nemzetközi orvostudományban csak 1900 után jelent meg intézményesült formában a szexológia. Elsőként, 1906-ban Ivan Bloch jelentetett meg egy kötetet, a Korunk nemi élete címü tudományos müvet (Bloch, 1909). Ebben a könyvben nemcsak a szexualitás helyét határozta meg a társadalomban, és írta le természetesen az orvosi vonatkozásait, hanem a nemi nevelés iskolai, részletesen kidolgozott tananyagát is közli. 
A reformpedagógia már 1907-ben szexuálpedagógiának nevezte e tárgyat, és négy fö szempontot tárgyalt: 1 . A nemi felvilágosítás a családban és az iskolában, 2. A nemileg érett ifjúság nemi felvilágosítása, 3. Tanítók és szülők tájékoztatása a nemi felvilágosítás dolgában, 4. Nemi dietétika (az ókori értelemben vett egészségmagatartás) és nevelés. A hosszú évtizedekig érvényes kérdések ekkor hangzanak el elöször: mikor, ki, hogyan végezze az oktatást.

Az átfogó program egyértelmüen mutatja a felelősség megosztottságát a család és az iskola között, a tanári és szülöi felkészítés szükségességét. Auguste Forel (1923) zürichi pszichiáter professzor tíz alapvető diszciplínára osztotta a szexológiát, egyben több határtudományt is kijelölt: pornográfia, önerotika, művészet, vallás, politika, törvényhozás, etika, pedagógia, orvostudomány, történeti néprajz. Magnus Hirschfeld (1935), aki az első szexológiai intézetet alapította Berlinben, kiemelte az iskolai oktatás fontosságát.

A 19. század végén induló reformpedagógiai mozgalom célkitüzése a gyermekek, a nők felszabadítása volt, ami számos társadalmi szokás megváltozását vonta maga után. A nők munkába állása, tanulási lehetősége, önállósodása, a házasság válsága, a válás lehetősége, a kettős erkölcs módosulása, a szerelem és házasság kapcsolatának változása, a prostitúció szabályozottságának megszüntetése (abolicionizmus) stb. mind hatással voltak az újkori pedagógiai elvekre is. A reformpedagógia fó céljának a koedukáció megteremtését tekintette. E mozgalom képviselője volt Ellen Key, aki a szexuális nevelés alapjának a mind önmagunkkal, mind a partnerrel szembeni felelősségtudat kialakítását tekintette. A kapcsolat alapját a szerelem határozza meg, de akkor ellentétben áll a házasság addigi szokásával, vagyis a kényszerházassággal. Ugyanezt vonatkoztatta az anyaságra is. A nő nem kizárólag anya, feleség, hanem alkotó ember is egyben. Erkölcstelennek tart „minden szerelem nélkül való apaságot, anyaságot, minden felelősség nélküli apaságot, anyaságot, minden éretlen vagy elfajult embernek apaságát, anyaságát" (Foerster, 1909).

A gondolatmenettel témaként vetette fel a legitim-illegitim házasságot, anyaságot és a gyermeki státuszt.

A nemi felvilágosítás módszerére tettek különböző javaslatokat például Sigmund reáliskolai, Maria Lischewska népiskolai (Bloch, 1909) és Friedrich Wilhelm Foerster (1909) egyetemi tanárok. Sigmund csak a gimnáziumi tanulóknál kezdené az oktatást öt fokon (I., II., V., VI., VII. osztályban): 1. Az alsó osztályokban a felvilágosítás a nemi szaporodás néhány mozzanatára szorítkozik: emlősállatok fiataljainak keletkezése, születése, a rovarok tojásainak keletkezése, a halak és hüllők tojásainak tenyészővé tétele. 2 . A nemi élet fogalmának alkotása szintetikus formában, semmi lényeges mozzanatot el nem hallgatni, de a nemzés aktusát, mint kevésbé lényegeset, nem kell említeni. 3. Az emberről szóló minden nemi és patológiai dolog az egészségtan előadások körébe tartozik a VII. osztályban. 4. A VI. osztály természetrajzi tanítási anyaga csak az állattan legyen, 
az emberi testről csak a VII. osztályban legyen szó. 5. A szülöi értekezleten a szülők tudomására kell hozni, hogy milyen módon világosíttatnak fel gyermekeik az iskolában. Javasolja, a gimnázium ne csak a testi „gymnastikával”, hanem a lélekkel is foglalkozzék, erősítse meg a fiatalokban az erélyt és az egyéniséget.

Foerster képviseli a konzervatív nevelési elveket a haladókkal szemben. Könyvében hibáztatja az erotikum túlzott kultuszát, az ösztönöket szigorú elfojtással, vallásos hittel gondolja kordában tartani. Elítéli és összeköti a maszturbációt az egyik legsúlyosabb jellembeli hibával, a hazugsággal: „Omnis mastubor mendax (minden hazug egyben önfertözö). Vagyis milyen képtelen dolog külön nemi pedagógiát üzni” (Foerster, 1909). Egy fiúnak, egy férfinak nagy akarattal kell rendelkeznie - mondja -, le kell tudni gyöznie az ösztöneit, szexuális vágyait. Teljesen bünös dolognak tartja a szexuálpedagógiát.

Auguste Forel a nemi nevelést, az etikai oktatást úgy képzeli el, hogy meleg érzések, meggyőzések igazságának hatására nevelődik az ifjú, nem a hideg moralizáló, száraz, unalmas, hamis oktatásra.

Mindenképpen a koedukáció mellett áll ki: „Ha a koedukációról van szó, rendesen még azt az ellenvetést halljuk, hogy a nő lénye és hivatása különbözik a férfitól, miért is az oktatásnak különbözőnek kell lennie. Erre azt válaszoljuk: a világ tárgyai, az emberi tudás anyaga, más szóval a tantárgyak: ugyanazok. A mily kevésbé beszélhetünk katolikus, vagy protestáns kémiáról, növényekről állatokról, hegyekről és tengerekről, éppoly kevéssé lehet ezeket a tárgyakat »fiúk« és »lányok« számára valóknak osztályozni” (Forel, 1923).

A századforduló Európa-szerte egyik legnagyobb egészségi problémája a szifilisz rohamos terjedése volt. Nem véletlenül szaporodnak a századforduló táján a fiatalokat óvni akaró javaslatok. Kiemelkedik közülük Szatmári Imre tanulmánya Fracastoro tankölteményéröl (Forrai, 2016).

1907-ben alakult meg a Nemi betegségek legyőzésére nevű társaság. A III., mannheimi kongresszusán ütköztek össze élesen a haladó liberális, feminista és konzervatív erők. A konferencián elhangzott, hogy a szexuális nevelést a családban kell elkezdeni, és az iskolában kell folytatni. Természetesen ebben sem értettek egyet azok, akik tenni is akartak az ifjúságért. Nagy vonalakban három irányvonal bontakozott ki mind a nemzetközi, mind a hazai szakemberek között.

1. A keresztény felfogás a nemiség problémáját kizárólag erkölcsi kérdéssé tette, melyet egy idézettel jellemezhetünk: Ignoti nulla cupido - a tudatlannak nincsenek vágyai. Vezető élharcosai Prohászka Ottokár, Tóth Tihamér, André Tisso. Kevésbé elvakult, de konzervatív felfogásban Foerster képviselte e nézetet.

2. A természettudományi nézet a testi-lelki egészségnevelés fejlesztését szorgalmazta. Képviselői Liebermann Leó, Grósz Emil, Lenhossék Mihály, Moravcsik Ernő, Jean Alfred Fournier, Albert Eulenburg, Heim Pál, Totisz Béla, Juba Adolf, olyan nagy elödök tiszteletben tartásával mint Jean Jacques Rousseau, Joachim Heinrich Campe. 
3. A feminista felfogás szerinti képviselők természettudományi kérdéssé tették a nemiség problémáit, amit a nőkérdés megoldásával együtt kell kezelni. Ezt hangsúlyozta Ellen Key, Maria Lischewska, Szatmári Imre, Emődi Aladár.

\section{HOL FOGLAL HELYET KEMÉNY FERENC MUNKÁSSÁGA?}

A magyar pedagógiai diskurzus egyik meghatározó auktora Kemény Ferenc (1860-1944) magyar sportszervező, pedagógus, tanügyi író, humanista békeharcos, az újkori olimpiai játékok kezdeményezője és elindítója, a Nemzetközi Olimpiai Bizottság alapító tagja, a Magyar Olimpiai Bizottság alapító titkára, a Magyar Paedagogiai Társaság tagja.

Kemény nemcsak a nemzetközi és hazai sportélet megszervezője, aktivistája, hanem 1894-től kiváló - budapesti reáliskolai - tanár és tankerületi föigazgató is. Széles látókörét már a Sorbonne-on töltött egyetemi évei alatt tágította, s nemzetközi tapasztalatait az oktatás területén is felhasználta. Oktatási elveinek alapját az az erkölcsi meggyőződés motiválta, hogy a kivárás, a nemi hüség, az önkielégítés elkerülésére az aktív sportolás kellően megvédi a tanuló ifjúságot a fokozott szexuális vágytól és az azzal összefüggő esetleges fenyegető nemi fertőződéstől.

Szakírói tevékenységét könyvekben és cikkekben fejtette ki. Egyik legfontosabb írása (Kemény, 1907, 9.), melyben az oktatás, illetve a pedagógiai módszerek határait tisztán látja:

„Kézséggel elismerem: a nemi élet eszményi tisztasága az egyetem, a köz körében merő utópia, mert valamint a természet irtózik az aboszolúttól, az emberiségből sem lehet a bünöket teljesen kiirtani. A világ mechanizmusa, úgy látszik, nem lehet el azon kivételek (bünök) nélkül s végső eredményben mindenütt kompromisszummal állunk szemben. [...] A problémának két főtengelyében: a felvilágosítás és az abstinencia kérdésében fogok bővebben kifejteni a szexuális pedagógiának modern és túlzó képviselöit nem igen fogja kielégíteni, de én a gyakorlati pedagógia szilárd talaján állva, egy percre sem feledkezem meg ennek reális viszonyairól s nem áhitozom azon szobatudós babérjaira, aki egy merőben elméleti erkölcstan felállításában leli gyönyörüségét." (Kemény, 1907, 9.)

Kemény Ferenc egyén és társadalom együttes problémájaként kezeli a nemiséget. Több szinten, többféle nevelési és egyben ellenőrzési „,szakembert”, módszert és színteret nevez meg, akik segíthetnek a fiatalok helyes nemi nevelésében.

Elsősorban a család: apa és anya, akiknek ez a hivatása, a gyereket körülvevő felnőtteknek nagy a befolyásuk a kiskorúakra, a nevelők, nevelőnők és cselédség.

A fiatalokkal foglalkozó orvosok (háziorvos, iskolaorvos, tisztiorvos), kiknek hatáskörébe tartozna a szakszerü, főleg biológiai felvilágosítás és nevelés.

Pedagógiai szempontú nevelésre az iskolában kerülne sor, ahol együttes nevelésben (coeducatio) mindkét nembeli tanerők és igazgató, az iskolaszékek tanügyi 
hatóságai vennének részt. Az egészségtan kötelező tanítása szükségszerü. A pedagógiai ellenszerek legfontosabb eszköze a testgyakorlatok rendszeres végzése.

Kemény szerint nem elhanyagolhatóak az öröklött hajlamok, a hiperszexualitás, melyeket figyelembe kell venni.

A dietétikára, vagyis a helyes életmódra oda kell figyelni: fontos a táplálkozás (a hús, az alkohol, a káros, luxusételek elkerülése). Ruházatban is az egyszerű és kényelmes viselése a javallt.

A fontos tényezők közé tartozó szociológiai és irodalmi szempontok: veszélyes egy gyermekre napi útja az iskoláig és onnan hazaérkezésig. Ebbe beletartozik az iskola környéke, a színházak és a mulatóhelyek. A képekkel illusztrált lapok, a ponyvairodalom, az ifjúsági rovatok mind károsan hathatnak. Nem kivételek a múzeumok és az utcai kirakatok sem. Érzékiséget sugall a zene, bizonyos művészetek és a tánc (Kemény, 1903).

Az érzékiség ellen határozottan és keményen küzd: ,az egész világ Vénusz asszony kötényébe kapaszkodik, a szexualizmus mindent megsemmisítő világostorrá lett, mely hatalmasabb lett a gőznél, villanyosságnál és a dinamitnál" (Kemény, 1900, 22.).

Figyelmeztet, hogy a gyerek egész környezete érzékiséget sugall: „Mi a botrányos, erkölcstelen? A pesti élet, a színház, a pornográfia... veszedelmes alkalmak, gyerekszoba, internátus, tánciskola, szomszédság, cselédek, felügyelet nélküli társalgás lányokkal, titkos levelezés, »post restante« pikáns levelezőlapok, kocsmázás, tulságos izgalma az érzékiségnek...” (Kemény, 1900, 22.)

Szembeszáll az eddigi nézettel: Ignoti nulla cupido (a tudatlannak nincsenek vágyai) (Kemény, 1903, 12.). Oktatási módszerének mind az aktív, mind a passzív formáját ajánlja: beszélni kell bizonyos dolgokról, például az igazságot közölni kell, az érzelem és értelem összeütközéséről is kötelesség szót váltani, de a kényesebb részeket egy „asztalon felejtett” szakkönyv oldja meg (Kemény, 1903, 14.).

A felvilágosítás különböző korosztályokra bontása más-más oktatási és tartalmi szinteket jelöl, például az általános kérdés felvetésekor: Hogy születik a gyermek? Mindenképpen az őszinteségre kell törekedni, de korlátok között, például az anyának gyereke van, a fának gyümölcse, a madárnak fiókája. Míg négy-öt évesen a gólyamese még elmegy, a későbbi korosztályt érzelmi alapú háttérrel kell felvilágosítani. Ugyanakkor kiáll a szüzesség, a nemi absztinencia fontossága mellett (Kemény, 1903, 18.).

Az erkölcsről, mint állandó természeti erőröl beszél: „erkölcsi lelkiismeret, amely nem mesterséges alkotás, hanem természetnek adománya és követelménye" (Kemény, 1903, 30.).

Az iskolák szerepe fontos, mivel a szülők nem végzik el a felvilágosítás feladatát, így marad az iskolai „tömeg”-oktatás, amelyet az iskolaorvos végez. A legnagyobb bünről, az onániáról tart előadást, felismerve az „első gyanus jelt: a kezek a zsebben, de teljes bizonyíték az önvallomás és a tettenérés" (Kemény, 1903, 41.). 
Az érzékiség ébrentartásában az iskola is hibás, mert az iskolai padok szerkezete, ellentétben az otthoni párnás székekkel, a keresztezett lábak, a póznán való mászás, a hosszú időzés illemhelyeken, az érzéki olvasmányok, az egymásnak megmutatott képek, az utcán látható plakátok, a mulatók, színházak, tárlatok mind sugallják az erotikát.

Külön figyelmet kell fordítani a tanuló ifjúság olvasmányaira, kiküszöbölve az erotikus elemeket tartalmazó könyveket: így fennakadnak az erkölcsi hálón azok a világirodalmi klasszikus gyöngyszemek, amelyeket meg kell gondolni, kézbe adhatóak-e, például Hamupipőke, Hófehérke, Biblia, Rachel, Ádám, Éva, Homérosz, Shakespeare, Zolák, Ibsenek, Tolsztojok, a magyar történelemből Bánk és Melinda, Zách Klára stb. Így szinte alig marad olvasmányuk a fiataloknak.

Családon belül az anyát is be kell vonni a tudatos nevelésbe. Gondos figyelmet kell fordítani a táplálkozásra, kerülni kell a fényüző ételeket, nevezetesen olyanokat, melyek elősegítik az érzékiséget, mint például a húst, az alkoholt, a teát mint izgatószereket.

A szép beszéd, káromkodás nélkül, az öltözködés figyelme, az egyszerü ruházat, az általános nevelési elvek betartása, a nemes példaadás, a tekintély emelése, egészség és tisztaság törvényeinek gyakorlata, kedély, vidámság a rosszkedv és unalom ellen, az önuralomra szoktatás és az olvasmányok ellenőrzése mind segíti a fiataloktól elterelni az erotikus fantáziálást.

Kemény komoly erőfeszítéseket tesz a sport bevezetésére az iskolai oktatásban. A versenyszerü játékok rendezése (az egri iskolában kis olimpiát rendezett), a testi nevelésre való figyelés, a több mozgás, a friss levegőn való játék a legfontosabb nevelö módszerei közé tartozik. Ehhez természetesen még hozzájön a hangsúlyos vallási érzület kialakítása, például „Isten bölcsességét, jóságát a szabad természetben szemléltessük"; szerinte a jó és szép iránti dalok megismertetése, a zene szeretetének ápolása jelenti a helyes nevelést. Kiemeli az akarat nevelését, ,a jövő azé a népé, amely a legnagyobb lelki szellemi és testi tökéletességel [sic!] a legnagyobb érzéki ellenállóképességét egyesíti” (Kemény, 1900, 97-98.).

Társadalmi javaslata: a helyes családi nevelést a háziorvos felügyelje (Kemény, 1900, 82-83.).

A Petőfi Társaság pedig ellenőrizze a színházi előadásokat, a sajtót, nem cenzúra gyanánt, de hogy látogathatják-e gyerekek az adott színdarabot, vagy olvashatják-e a könyvet az erotika szempontjából. Elutasítja a müvészetekben a meztelenséget, a századforduló új szakágait, a mozdulat- és táncművészetet: „lábművészet aranykora, meztelen táncosnők", akik káros hatással vannak a fiatalokra.

Az oktatási elveinek alapját az az erkölcsi szemlélet motiválta, hogy a kivárásra, a nemi hüségre való buzdítás, az önkielégítés elkerülése (amely csak a vágyakat gerjeszti), valamint az aktív sportolás kellően megvédi a tanuló ifjúságot a zülléstől és a nemi fertőződésektől. 


\section{IRODALOM}

Bloch, I. (1909): Korunk nemi élete. (6., átdolgozott kiadás) Budapest: Dante (eredeti megjelenés: Das Sexualleben unserer Zeit in seinen Beziehungen zur modernen Kultur. Berlin: 1906)

Buda B. (1994): Szexuális viselkedés. Budapest: Animula Kiadó

Foerster, Fr. W. (1909): A nemi élet etikája és pedagógiája. Budapest: Szent István Társulat

Forel, A. (1923): A nemi kérdés. (13. átdolgozott kiadás) Budapest: Nova Irodalmi Intézet (eredeti megjelenés: Die sexuelle Frage. München, 1905)

Forrai J. (2016): Szifilisz hexameterekben - modern pedagógiai módszer a századfordulón. Magyar Tudomány, 177, 3, 332-339. http://www.matud.iif.hu/2016/03/11.htm

Foucault, M. (1996): A szexualitás története. Budapest: Atlantisz Kiadó

Fournier, A. (1904): Tizennyolcz éves fiainknak. Budapest

Hirschfeld, M. (1935): Sex in Human Relationships. London: John Lane the Bodley Head

Kemény F. (1900): Küzdelem az érzékiség ellen. Katolikus Tanügy. A nevelés és tanitásügy összes ágait felölelö kath. paedagogiai szakközlöny. A „,Magyar Állam” melléklapja, VI, 8, ápr. 22.

Kemény F. (1903): Az érzéki ösztönök korai ébredésének leküzdésére szolgáló elvek. Egészség, febr. 50.

Kemény F. (1907): A nemi probléma (sexuális pedagógia). Gyakorlati tanácsok az erkölcsi nevelésre és a korai érzékiség leküzdésére, tanférfiak és szülök részére. [könyvismertetés] Népnevelök Könyvtára, 33. füzet, IX, 1. 